\title{
Coeval folding and boudinage under plane strain with the axis of no change perpendicular to the layer
}

\section{Enama Mengong · G. Zulauf}

Published online: 22 June 2006

(C) Springer-Verlag 2006

\section{Int J Earth Sci (2006) 95:178-188}

Unfortunately, two errors occured in the original article. The corrections are shown below.

In the abstract, it must read:

"...If the viscosity ratio is large (ca. $>20$ ) and the initial thickness of the competent layer is small, both folds and boudins develop simultaneously ... ."

Figure 3 was published incomplete in the original article. The corrected figure is shown here.

The online version of the original article can be found at http://dx.doi.org/10.1007/s00531-005-0032-z

M. E. Mengong $(\bowtie) \cdot$ G. Zulauf

Geologisch-Paläontologisches Institut der Universität

Frankfurt a.M., Senckenberganlage 32-34,

60054 Frankfurt a.M., Germany

e-mail: M.Enama-Mengong@em.uni-frankfurt.de

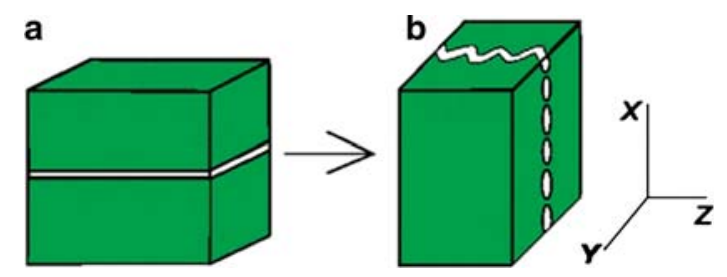

Fig. 3 Schematic drawing of undeformed (a) and deformed sample (b) 